\title{
Influência de paradigmas temporais em testes de processamento temporal auditivo****
}

\author{
Influence of temporal aspects in auditory temporal processing tests
}

\author{
Cristina Ferraz Borges Murphy * \\ Eliane Schochat **
}

\begin{abstract}
* Fonoaudióloga. Doutoranda em Ciências da Reabilitação pelo Departamento de Fisioterapia, Fonoaudiologia e Terapia Ocupacional da Faculdade de Medicina da Universidade de São Paulo. Endereço para correspondência: Avenida Padre Antonio José dos Santos, 313 - Apto. 134 - São Paulo - SP - CEP 04563-010 (crist78@yahoo.com)

**Fonoaudióloga. Professora LivreDocente do Curso de Fonoaudiologia do Departamento de Fisioterapia, Fonoaudiologia e Terapia Ocupacional da Faculdade de Medicina da Universidade de São Paulo.

***Trabalho Realizado no Centro de Docência e Pesquisa do Departamento de Fonoaudiologia, Fisioterapia e Terapia Ocupacional da Faculdade de Medicina da Universidade de São Paulo
\end{abstract}

Artigo de Pesquisa

Artigo Submetido a Avaliação por Pares

Conflito de Interesse: não

Recebido em 17.11.2006.

Revisado em 18.06.2007; 19.07.2007. Aceito para Publicação em 19.07.2007.

\begin{abstract}
Background: auditory temporal processing. Aim: to compare the performance of children in auditory temporal processing tests according to different temporal variables such as inter-stimulus interval, stimuli duration and type of task (discrimination or ordering). Method: 27 children, with ages between 9 to 12 years, were evaluated. In order to analyze the effect of temporal variables, an adaptation of the American "Repetition test" was developed, containing four tests of frequency discrimination and ordering, and four tests of temporal discrimination and ordering. In order to investigate the variable 'type of requested task', tests involving frequency and temporal discrimination and ordering were elaborated. In order to evaluate the variable 'stimulus duration', frequency discrimination and ordering tests were elaborated, with stimulus durations of $200 \mathrm{~ms}$ and $100 \mathrm{~ms}$. In addition, temporal discrimination and ordering tests were carried out, with stimulus durations of $200 / 400 \mathrm{~ms}$ and $300 / 600 \mathrm{~ms}$. In order to evaluate the variable 'inter-stimulus interval', tests were elaborated with randomly variable inter-stimulus intervals, ranging between 50ms and 250ms. Results: regarding inter-stimulus interval, there was no statistically significant difference between the average number of correct answers when intervals varied between 50 and $250 \mathrm{~ms}$, in all of the tests. Regarding stimulus duration, the research group presented a poor performance for when stimulus had a shorter duration (100ms), compared to those with longer duration, but only in the tests involving frequency. Regarding order, the research group presented a poor performance in ordering tasks when compared to discrimination tasks. Conclusion: temporal variables such stimuli duration and type of task (discrimination and ordering) can interfere in the performance of children in tests of auditory temporal processing.
\end{abstract}

Keywords: Hearing, Hearing Tests, Children.

\section{Resumo}

Tema: processamento temporal auditivo. Objetivo: comparar o desempenho de crianças, em testes de processamento temporal auditivo de acordo com diferentes paradigmas temporais como intervalo interestímulos, duração do estímulo e tipo de tarefa solicitada (discriminação ou ordenação). Método: foram avaliadas 27 crianças de 9 a 12 anos. Para analisar o efeito de cada variável temporal, foi desenvolvida e aplicada uma adaptação do teste americano "Repetition Test", contendo quatro testes de discriminação e de ordenação de frequência, e quatro testes de discriminação e de ordenação de duração. Para investigar a variável "tipo de tarefa solicitada", foram elaborados testes envolvendo discriminação e ordenação de frequência e discriminação e ordenação de duração. Para investigar a variável "duração do estímulo", foram elaborados testes de discriminação e ordenação de freqüência com estímulos de $200 \mathrm{~ms}$ e $100 \mathrm{~ms}$ e testes de discriminação e ordenação de duração com estímulos de 200/400ms e 300/600ms. Para investigar a variável "intervalo inter-estímulos", foram elaborados testes com intervalos inter-estímulos variáveis aleatoriamente entre $50 \mathrm{~ms}$ e $250 \mathrm{~ms}$.Resultados: em relação à variável intervalo inter-estímulos, não houve diferença estatisticamente significante entre a média de acertos quando os intervalos variavam de 50 a $250 \mathrm{~ms}$, em todos os testes realizados; em relação à duração do estímulo, o grupo apresentou pior desempenho para estímulos com menor duração (100ms) em comparação com estímulos maiores, mas apenas nos testes envolvendo freqüência; em relação à ordem solicitada, o grupo apresentou pior desempenho nas tarefas de ordenação, se comparada com discriminação. Conclusão: variáveis temporais como duração do estímulo e tipo de ordem solicitada (discriminação e ordenação) podem interferir no desempenho de crianças em testes de processamento temporal auditivo.

Palavras Chave: Audição; Testes Auditivos; Criança.

Referenciar este material como:

1 MURPHY, C. F. B.; SCHOCHAT, E. Influence of temporal aspects in auditory temporal processing tests (original title: Influência de paradigmas temporais em testes $\sum 3$ de processamento temporal auditivo). Pró-Fono Revista de Atualização Científica, Barueri (SP), v. 19, n. 3, p. 259-266, jul.-set. 2007. 


\section{Introduction}

The way the human brain realizes and discriminates the complex and fast speech sounds components are still discussed (Frisina, 2001), nevertheless it is known that the codification of temporal information of the sound, such as its duration, interval and presentation order of the stimuli, provides vital information for the nervous system. This is because, in continuous speech the speech segments are co-articulated, that is, their acoustic pattern is modified regarding the duration, intensity and frequency. Thus, the listener has to analyze the acoustic clues the speaker produced, organizing the speech segments from the acoustic point of view, in a sequential order defined by his language's patterns (Balen,1997).

Nowadays, it is known that the human ear is able to realize two sounds when they are separated by an interval longer than 2 milliseconds (Hirsh, 1959). Sounds can also be ordered when the interval between them is from 20 to 40 milliseconds, approximately (Kanabus et al,2002), however, this threshold can vary according to the parameters used in the task, such as inter-stimuli interval, for instance (Kanabus et al,2002). Furthermore, in certain populations, such as in the elderly (Neves, 2002; Mendelson \& Riccketts,2001) and in children with language disorders (Rosen \& Manganari, 2001, Borges \& Schochat, 2005a, Furbeta \& Felippe, 2005), where there is an alteration in the Auditory Processing, such threshold may also have a different value.

Mendelson and Riccketts (2001) affirmed that an alteration in the fast processing of complex acoustic clues may be one of the reasons for the poor speech discrimination in the elderly. In their researches, the authors were able to relate the individual's age to the decrease of the perception of the frequency change rate of speech sounds, which could lead to a poor discrimination.

Regarding the language disorders, one of the hypotheses related to the etiology of the problem is the existence of perceptual basis problems. These difficulties would involve the temporal processing of auditory, visual and sensory-motor stimuli presented quickly and sequentially. This theory tries to conciliate auditory and visual deficits through a single basis, the temporal processing (Rosen \& Manganari, 2001).

Researches have also showed that the linguistic experience may interfere in ability to realize temporal characteristics of the acoustic signal (Gandour et al,2002; Klein et al,2001).
Phonemes are more easily discriminated in Portuguese than in English, and therefore there is less effort of the auditory system, resulting in a poorer discrimination in temporal tasks involving frequency and duration (Schochat \& Musiek, 2006).

Considering the fact that the auditory temporal processing is closely related to the speech perception, it is extremely important the use of tests involving temporal skills in individuals with oral and written language complaints, and in the battery of tests for the auditory processing evaluation (Samelli, 2005). Thus, the investigation about temporal parameters present in the tests is also important.

Chermak and Lee (2005), for example, compared the performance of American children in 4 different auditory temporal processing tests aiming to analyze if differences between the stimuli or the tasks requested in each test could interfere in the diagnosis of each child. The analyzed tests were: RGDT (random gap detection test), AFTR (auditory fusion test-revised), GIN (gap in noise) and BFT (binaural fusion test). Results showed that all children presented results within normality patterns in all tests, which demonstrated that there are no significant differences between the temporal parameters used in each test.

In Brazil there isn't a criterion regarding the selection of temporal tests used in the auditory processing evaluation, as well as there aren't researches that show the interference of temporal parameters in the performance for each one. Thus, the aim of this study is to compare the performance of children in auditory processing tests according to different temporal paradigms, such as inter-stimuli interval, stimulus duration and type of task requested (discrimination or ordering). This way, it will be possible to analyze how temporal variables influence the performance of children in auditory temporal processing tests.

\section{Method}

The study was approved by the Ethics Committee for Research Projects Analysis CAPPesq of the clinical board of the Clínicas Hospital of the Medical School of University of São Paulo (FMUSP), in 9/10/2002, Research Protocol n 649/01.

\section{Subjects}

Data collecting was performed in the Speech and Hearing Investigation Laboratory in Auditory Processing of the Speech and Hearing Course of 
FMUSP during January and March, 2004. The 27 participants came from private schools near the area where data were collected. Children should be between 9 and 12 years and 11 months of age, and should present results within the normality patterns in the Basic Audiological Evaluation (audiometry, speech audiometry and immitance measures). Through the anamnesis, it was verified that all participants did not present cognitive, psychological, neurological, and ophthalmological alterations. Furthermore, they didn't present academic complaints, otitis background or musical knowledge. All participants consented to participate and allowed the publication of the results.

\section{Material}

Individuals were submitted to a series of procedures: clinical story, complete audiological evaluation composed by otoscopy, immitance measures, tonal audiometry and speech audiometry. After these procedures, children who did not meet the inclusion criteria described above were excluded, and when it was necessary they were referred to the responsible Professional. Once the group was selected, the following tests were applied:

Auditory progressive temporal test (Borges \& Schochat, 2005b)

The eight tests related to the auditory temporal processing were applied in an isolated and silent room, through a CD played in a LG computer with the Windows Media Player program, and using a Pioneer earphone SE-A20. The CD with the test recording was recorded in the Radio Laboratory of the Arts and Communication School (ECA) of USP, using the Software Sound Forge 4.5. For the recording, a mixing console MACKIE SR 32-4 and a CD recorder HP 8100 were used. The recording was performed directly in the computer's Hard Disc with a Pentium processer. The introduction of the tests (naming) was done by a locator using a SM81LC microphone.

In order to analyze each temporal variable separately, eight tests were applied. The difference between each test is described in Table 1 .

The inter-stimuli intervals chosen (50 to $250 \mathrm{~ms}$ ) were based on the results found by Tallal (1980). This interval seems to be critical in stimuli discrimination and ordering tasks, either in control group as in English speaking children with language disorders. Thus, in order to analyze different values considering this interval, we chose to vary them in steps of 50ms, randomly presented.

The other variables, such as stimulus duration and frequency were based on pilot studies performed with Portuguese speaking children.

Each discrimination test has 40 attempts, that is, 40 pairs of stimulus, and each ordering test has 30 attempts, that is, 30 pairs of stimulus. Each stimulus presents a rise and fall of $5 \mathrm{~ms}$.

The participant and the researcher remained side by side, in front of the computer. In he screen it was possible to visualize the program used to run the CD (track, seconds played and left). Tests were applied in a comfortable intensity, corresponding to 70dBHL according to the Sound Pressure Level Measure. The stimuli are binaural, that is, presented simultaneously in both ears. The response given was verbal: in discrimination tests the participants should say if the stimuli were the same or different, and in ordering tests, they should say the order of presentation (high/low or low/high).

TABLE 1. Description of each auditory temporal test.

\begin{tabular}{l|l|l|l|l|}
\hline & frequency & $\begin{array}{l}\text { Stimulus } \\
\text { duration }\end{array}$ & Type of task & inter-stimuli intervals \\
\hline Test 1 & $1000 / 1400 \mathrm{~Hz}$ & $200 \mathrm{~ms}$ & ordering & $50,100,150,200,250 \mathrm{~ms}$ \\
\hline Test 2 & $1000 / 1400 \mathrm{~Hz}$ & $100 \mathrm{~ms}$ & ordering & $50,100,150,200,250 \mathrm{~ms}$ \\
\hline Test 3 & $1000 \mathrm{~Hz}$ & $300 / 600 \mathrm{~ms}$ & ordering & $50,100,150,200,250 \mathrm{~ms}$ \\
\hline Test 4 & $1000 \mathrm{~Hz}$ & $200 / 400 \mathrm{~ms}$ & ordering & $50,100,150,200,250 \mathrm{~ms}$ \\
\hline Test 5 & $1000 \mathrm{~Hz} / 1400 \mathrm{~Hz}$ & $200 \mathrm{~ms}$ & discrimination & $50,100,150,200,250 \mathrm{~ms}$ \\
\hline Test 6 & $1000 \mathrm{~Hz} / 1400 \mathrm{~Hz}$ & $100 \mathrm{~ms}$ & discrimination & $50,100,150,200,250 \mathrm{~ms}$ \\
\hline Test 7 & $1000 \mathrm{~Hz}$ & $300 / 600 \mathrm{~ms}$ & discrimination & $50,100,150,200,250 \mathrm{~ms}$ \\
\hline Test 8 & $1000 \mathrm{~Hz}$ & $200 / 400 \mathrm{~ms}$ & discrimination & $50,100,150,200,250 \mathrm{~ms}$ \\
\hline
\end{tabular}




\section{Results}

The effect of the three temporal variables was analyzed separately, using the ANOVA technique.

Concerning the inter-stimuli intervals (ISIs), the number of correct responses for each interval was totalized for each participant and, then the average of correct responses was calculated for the group, which can be seen in percentage in Figure 1. There was no significant statistical difference between the average obtained for each inter-stimulus interval analyzed $(\mathrm{p}=0.61)$. There wasn't a great standard deviation for each analyzed IIE (interstimuli intervals) either, which can be observed by the upper and lower limits of the figure.

The analysis of the stimuli duration effect was also analyzed (Figure 2). The duration 1 corresponds to $200 \mathrm{~ms}$ in tests involving frequency, and $300 / 600 \mathrm{~ms}$ in tests involving duration; and the duration 2 corresponds to $100 \mathrm{~ms}$ and $200 /$ $400 \mathrm{~ms}$. Thus, we compared the group performance regarding duration 1 and 2 in tests involving frequency and duration. The group presented significant statistical difference for all comparisons: between the frequency discrimination tests $(p=0,004)$, between duration discrimination tests $(p=0,006)$, between ordering and duration tests $(p<0,001)$, except for the Frequency Ordering test $(p=0,715)$, and the longer the stimuli, the better the performance.

The type of task requested (discrimination $\mathrm{x}$ ordering) was also compared (figure 3). Thus, figure 3 demonstrates the performance in frequency discrimination and ordering tests with short duration $(200 \mathrm{~ms})$, which represents frequency 1 , and with long duration, which represents frequency $2(200 \mathrm{~ms})$. The performance in discrimination and ordering tests of duration 1 (300/600ms) and duration 2 (200/400ms) was also compared. Results demonstrated significant differences only between tests involving frequency (pfreq. $1<0,001$, pfreq. $2<0,001$ ), and the discrimination task (disc.) presented better performance when compared to the ordering (ord.) task. Concerning the tests involving duration, there was no significant statistical difference regarding the requested task ( $\mathrm{p}$ dur. $1=0,836$ and p.dur. $2=0,320)$.
FIGURE 1. Percentage of correct responses according to the IIEs

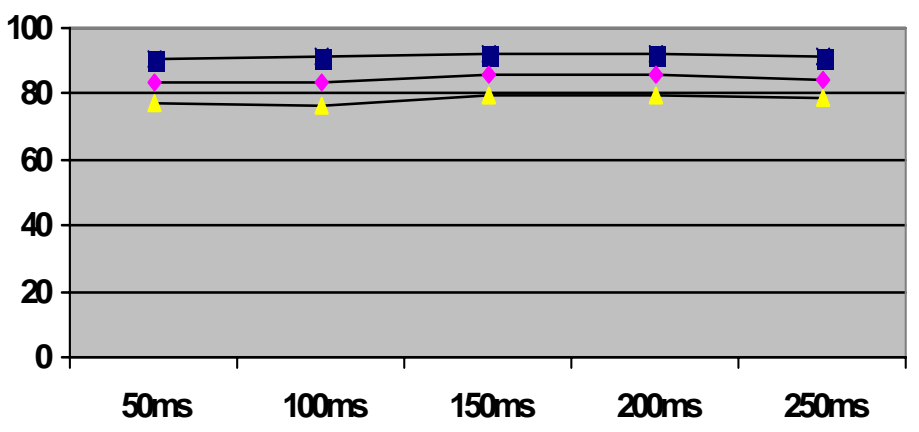

- upper limit $\rightarrow-$ average - - lower limit

FIGURE 2. Percentage of correct responses according to the stimuli duration.

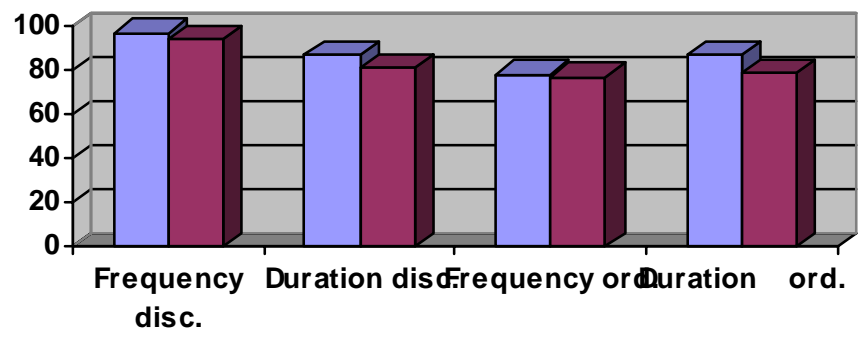

$\square$ duration $1 \square$ duration 2

FIGURE 3. Percentage of correct responses according to the task

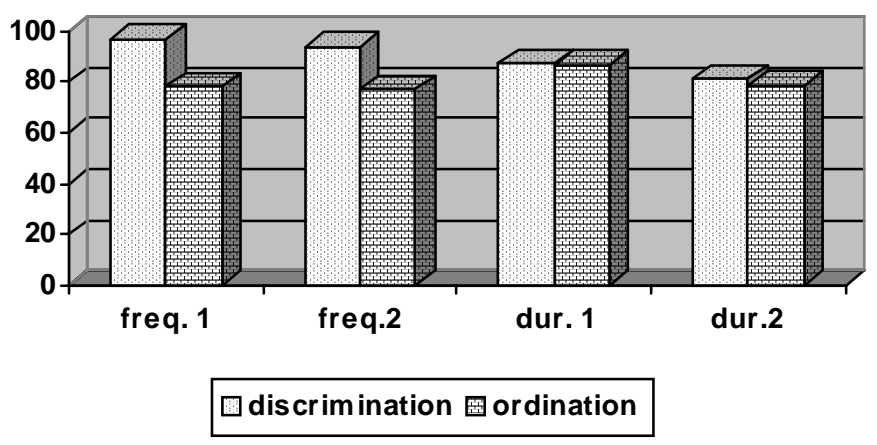




\section{Discussion}

The present study aimed to analyze the effect of temporal variables of a test battery of auditory temporal processing in children. The analyzed variables are the inter-stimuli interval, the stimulus duration and the type of order requested.

Concerning the inter-stimuli intervals, the intervals from 50 to $250 \mathrm{~ms}$ were analyzed in eight tests. Results showed that they didn't influence the performance of the group.

A different result was found by Kanabus et al (2002). The authors performed frequency ordering tasks in adults. The pairs of stimuli presented 300 and $3000 \mathrm{~Hz}$ and duration of $15 \mathrm{~ms}$. The inter-stimuli intervals considered were: 5,10,20,40,80,150,300 and $500 \mathrm{~ms}$. The percentage of correct responses increased with the increase of the IIEs, and the interval that presented a great increase of the number of correct responses was between 40 and $80 \mathrm{~ms}$. Therefore, in this research, we should have found this difference between 50 and $100 \mathrm{~ms}$, approximately.

However, Kanabus et al (2002) have also found that the IIEs threshold requested for the acoustic stimuli ordering ( $75 \%$ of correct responses) is near $40 \mathrm{~ms}$. In the present research, for all analyzed ISIs the percentage of correct responses was above $75 \%$, even for $50 \mathrm{~ms}$. This shows that maybe if we had included ISIs with shorter durations, we would have found differences in the performance for each one of them. Maybe, there aren't significant differences above the threshold concerning the difficulty levels.

Another hypothesis to be considered is the influence of other temporal parameters, such as the stimulus duration. Kanabus et al (2002) used stimuli with $15 \mathrm{~ms}$, while in the present research stimuli with 100 or $200 \mathrm{~ms}$ were used. There might be a correlation between these different temporal variables; this hypothesis may be accepted if we consider the temporal integration phenomena, which show a relation between a stimulus duration and its detection threshold (Shinn, 2003, Pulgati,2001).

The interference of the Language should also be considered. No similar studies were found in Portuguese speaking subjects, but similar tests were already applied in German speaking people (Heim et al, 2001). Heim et al (2001) did not observe influence of the IIEs varying from 8 to $305 \mathrm{~ms}$, in control group.

Therefore, although non verbal stimuli are used in researches as the ones mentioned above, the way how this stimulus is processed by different Languages speaking people may vary (Chermak \& Musiek, 1997). This is because each language requires a particular acoustic perception, once each one of them present specific phonetic characteristics. Thus, it seems that Languages such as English, that present a greater number of phonemes differentiated by the variable frequency, will present speakers with a more sensitive acoustic perception for this aspect than Portuguese speaking people, which present a greater number of phonemes differentiated by the variable duration.

Despite not including the "ordering threshold" in the research, there isn't a consensus regarding the threshold for other different populations, such as children with language disorder and aged people. Borges (2005) performed the same tests in children with reading disorders. These children had difficulty to perform the same tests (percentage of correct responses below $75 \%$ for all IIEs), but, accordingly, there was no significant difference between the analyzed IIEs. Thus, the threshold of children with this disorder may be above the analyzed ISIs, that is, above $250 \mathrm{~ms}$. The findings of Tallal and Piercy (1973) are another example of the same type of research, where the group of children with language disorder presented approximately $75 \%$ of correct responses for the IIEs of 300ms (ordering threshold).

We shall compare the analyzed tests with the ones used in the clinical practice, that were normalized for the Brazilian Portuguese (Schochat et al, 2000; Balen,2001). The version Audiology Illustrated (Musiek, 1994) contains the frequency pattern tests, presenting IIEs of $200 \mathrm{~ms}$, and the duration pattern test, with IIEs of 300ms. Therefore, comparing the data from Borges (2005) and from Tallal and Piercy (1973), it is easy to realize that the parameters of the version Audiology Illustrated (frequency), make the performance of the test difficult, that is, the analysis of the ordering task may be impossible by the parameters of such test.

The tests commercialized by Auditec of Saint Louis present ISIs of 300ms for frequency and duration, in the child and adult versions. Therefore, there is a higher possibility of a better application in a population with language disorders (BrancoBarreiro, 2003) or even in children users of cochlear implant (Frederigue, 2006)

Thus, it is observed that in both tests, the parameters are responsible for the difficulty degree 
of the test, not enabling its performance many times, and consequently the diagnosis conclusion. Maybe, in clinical terms the application of the test with varied parameters would be more indicated (psychophysical tests) in order to evaluate the performance of the individual according to the parameters present. The disadvantages of this type of test are the long time of application requested and the difficulty to establish comparison parameters.

These different parameters may also explain results within normality range in frequency pattern tests and altered results in duration pattern tests, and vice-versa, despite both of them evaluate the same skill.

The effect of the variable stimulus duration was also analyzed. The findings showed that there was a significant difference between the percentage of correct responses obtained in tests with duration 1 (200ms, 300/600ms) and 2 (100ms, 200/400ms); it was observed that the longer the stimulus duration, the better the performance. Only in the Frequency Ordering test, no significant difference was found. This result shows that this variable may interfere in the performance of the individual to be tested.

Thompson et al (2001) have also analyzed the performance of children and adults in frequency discrimination tasks using stimuli with different durations $(20 \mathrm{~ms}, 50 \mathrm{~ms}$ and $200 \mathrm{~ms})$. The researchers found that the stimuli duration is inversely proportional to the difference threshold between the frequencies, that is, the longer the stimulus duration, the smaller the difference, in $\mathrm{Hz}$ between the stimuli.

Wittmann and Fink (2004) discussed the use of different types of stimuli, regarding their duration, in researches involving language disorders. According to the researchers, the most used condition for this kind of population is the $75 \mathrm{~ms}$ one in psychophysical tests.

Tallal and Piercy (1973) compared the performance of children with language acquisition delay in two frequency ordering tests. Each test presented 3 stimuli with $75 \mathrm{~ms}$ and $250 \mathrm{~ms}$ of duration. When the stimuli presented $75 \mathrm{~ms}$ of duration, all children from the control group had a performance within the expected pattern, and only $17 \%$ of the study group presented performance similar to the control group. However, when the stimuli presented duration of $250 \mathrm{~ms}, 83 \%$ of the study group presented performance similar to the control group. A similar analysis was done by Heiervang et al (2002) using stimuli of 75 and $250 \mathrm{~ms}$ of duration in tests involving frequency discrimination and ordering. Results showed that both groups presented worse performance when the stimuli presented $75 \mathrm{~ms}$ of duration, when compared to those with $250 \mathrm{~ms}$, but this worsening was more evident in the group of dyslexic children. The authors discuss, therefore, the importance of the stimulus duration as a variable to be considered in researches involving dyslexia.

Let's consider again, the tests used in the clinical practice. The version Audiology Illustrated (Musiek, 1994) contains the frequency pattern tests presenting a constant duration of $150 \mathrm{~ms}$, and the duration pattern test with durations of 500 and $250 \mathrm{~ms}$. The tests commercialized by Auditec of Saint Louis present for the variable frequency, $500 \mathrm{~ms}$ duration in the child version and $300 \mathrm{~ms}$ in the adult version. The ordering tests present durations of $250 \mathrm{~ms}$ and $500 \mathrm{~ms}$. Therefore, it can be noticed that only tests involving frequency present different difficulty levels regarding the parameters stimulus duration.

The last variable to be considered is the type of task requested. Results showed that the performance of the group in tests involving frequency was influenced by the type of task (discrimination $\mathrm{x}$ ordering); the ordering task presented higher difficulty degree (figure 3 ). There was no significant difference in tests involving duration.

One of the hypotheses for not having found differences between tests involving duration would be the presence of arbitrary responses. Eddins et al (2001), for instance, affirm that memory and attention could contribute for the great variability in the performance in tests involving discrimination of duration acoustic clues.

Banai and Ahissar (2006) compared the performance of a control group and a group with learning disorder in tasks involving frequency. The researcher did not find differences between the discrimination threshold between frequencies in both situations when analyzing the control group. A difference was found for the group with language disorder. The author concludes that the ordering task was not more difficult for the control group.

Heiverang (2002) found a similar result. The researcher applied adapted tests of Tallal and Piercy (1973) in dyslexic children and in controls and observed that only the study group presented a great fall in the performance of discrimination tasks comparing to the ordering ones.

Therefore, one of the hypotheses for the result found in the present study is the great variability of responses for ordering tests which is different 
from other auditory processing tests that present greater reliability (Frasca, 2005). This hypothesis can also be corroborated by Berwanger et al (2004), who found that the applicability of temporal tests in children analyzed in research by test-retest is discussed. The authors affirm that there is a great variability of responses in children from the control group.

\section{Conclusion}

The research shows that variables such as stimulus duration and order requested can interfere in the individual's performance in auditory temporal tests. Concerning the stimulus duration, the longer the stimulus the better the performance. Concerning the type of task, the ordering skill presented higher difficulty degree if compared to the discrimination, in tests involving frequency. In conclusion, it is necessary a greater concern with temporal parameters present in each test, once these parameters directly influence the individual's performance, and maybe the diagnostic, requiring further investigation in future researches.

\section{References}

AUDITEC. Central auditory processing. Disponível em: <http://www.auditec.com>. Acesso em: out. 2006.

BALEN, S. A. Processamento auditivo central: aspectos temporais da audição e percepção acústica da fala. 1997. 175 f. Dissertação (Mestrado em Distúrbios da Comunicação) - Pontifícia Universidade Católica, São Paulo.

BALEN, S. A. Reconhecimento de padrões auditivos de frequência e de duração: desempenho de crianças escolares de 7 a 11 anos. 2001. 175 f. Tese (Doutorado em Psicologia) - Instituto de Psicologia, Universidade de São Paulo, São Paulo.

BANAI, K.; AHISSAR, M. Auditory processing deficits in dyslexia: task or stimulus related? Cereb. Cortex, Oxford, v. 16 , n. 12 , p. 1718-1728, jan. 2006.

BERWANGER, D.; WITTMANN, M.; STEINBUCHEL, N.; SUCHODOLETZ, W. Measurement of temporal-order judgment in children. Acta Neurobiol. Exp., Warszawa, v. 64, n. 3, p. 387-394, 2004.

BORGES, C. F. Processamento temporal auditivo em crianças com transtornos de leitura. 2005. $166 \mathrm{f}$. Dissertação (Mestrado em Ciências) - Faculdade de Medicina, Universidade de São Paulo, São Paulo.

BORGES, C. F.; SCHOCHAT, E. Fatores de risco para o transtorno do processamento auditivo. R. T. Desenv., v. 14 , n. 80 e n. 81 , p. $83-88$, maio-jun. 2005a.

BORGES, C.F.; SCHOCHAT, E. Processamento temporal auditivo em crianças que estudam música. R. Soc. Bras. Fonoaudiol., v. 10, n. 4, p. 226-231, out.-dez. 2005b.

BRANCO-BARREIRO, F. C. A. Estudo do processamento auditivo temporal em alunos de escola pública com e sem dificudades de leitura. 2003. Tese (Doutorado em Psicologia) - Instituto de Psicologia, Universidade de São Paulo, São Paulo.
CHERMAK, G. D.; LEE, J. Comparison of children`s performance on four tests of temporal resolution. J. Am. Acad. Audiol., Lewiston (NY), v. 16, n. 8, p. 554-563, sept. 2005.

CHERMAK, G. D.; MUSIEK, F. E. Central auditory processing disorders: new perspectives. San Diego: Singular Publishing Group San Diego, 1997.

EDDINS, A.; EDDINS, E.; COAD, M. L.; LOCKWOOED, A.; WATSON, C. Cognitive and sensory influence on the perception of complex auditory signals. J. Acost. Soc. Am., Lancaster (PA), v. 109, n. 5, p. 2475-2479, 2001.

FRASCA, M. F. S. S. Processamento auditivo em teste e reteste: confiabilidade da avaliação. 2005. $104 \mathrm{f}$. Dissertação (Mestrado em Ciências) - Faculdade de Medicina, Universidade de São Paulo, São Paulo.

FREDERIGUE, N. B. Reconhecimento de padrões auditivos de freqüencia e de duração em crianças usuárias de implante coclear multicanal. 2006. $158 \mathrm{f}$. Tese (Doutorado em Psicologia) - Instituto de Psicologia, Universidade de São Paulo, São Paulo.

FRISINA, R. D. Subcortical neural mechanisms for auditory temporal processing. Hear. Res., Amsterdam, v. 158, n. 1 e n. 2, p. 1-27, aug. 2001.

FURBETA, T. D. C.; FELIPPE, C. A. N. Avaliação simplificada de processamento auditivo e dificuldades de leitura-escrita. Pró-Fono R. Atual. Cient., Barueri (SP), v. 17, n. 1, p. 11-18, jan.-abr. 2005.

GANDOUR, J.; WONG, D.; LOWE, M.; DZEMIDZIC, M.; SATTHAMNUWONG, N.; TONG, Y.; LURITO, J. Neural circuitry underlying perception of duration depends on language experience. Brain Lang., Orlando (FL), v. 83, n. 2, p. 268-290, nov. 2002. 
HEIERVANG, E.; STEVENSON, J.; HUGDAHL, K. Auditory processing in children with dyslexia. Child Psychol. Psychiat., London, v. 43, n. 7, p. 931-938, oct. 2002.

HEIM, S.; FREEMAN, R. B.; EULITZ, C.; THOMAS, E. Auditory temporal processing deficit in dyslexia is associated with enhanced sensitivity in the visual modality. Neuroreport, Oxford, v. 12, n. 3, p. 35-42, mar. 2001.

HIRSH, J. Auditory perception of temporal order. $J$. Acoustic Soc. Am., Lancaster (PA), v. 31, p. 759-767, 1959.

KANABUS, M.; SZELAG, E.; ROJEK, E.; POPPEL, E. Temporal order judgment for auditory and visual stimuli Acta Neurobiol. Exp., Warszawa, v. 62, n. 4, p. 263-270, 2002.

KLEIN, D.; ZATORRE, R. J.; MILNER, B.; ZHAO, V. A cross-linguistic PET study of tone perception in Mandarin Chinese and English speakers. Neuroimage, v. 13, n. 4, p. 646-653, apr. 2001.

MENDELSON, J. R.; RICCKETS, C. Age-related temporal processing speed deterioration in auditory cortex. Hear. Res., Amsterdam, v. 158, n. 1 e n. 2, p. 84-94, aug. 2001. MUSIEK, F. E. Frequency (pitch) and duration patterns tests. J. Am. Acad. Audiol., Lewiston (NY), v. 5, n. 4, p. 265-268, jul. 1994.

NEVES, V. T. Envelhecimento do processamento temporal auditivo. Psic. Teor. Pesq., Brasília, v. 18, n. 3, p. 275282, dez. 2002.

PULGATI, G. H. Latência e acurácia de respostas a estímulos visuais de crianças portadoras de desordem do processamento auditivo central. 2001. Dissertação (Mestrado em Psicologia) - Instituto de Psicologia, Universidade de São Paulo, São Paulo.
ROSEN, S.; MANGANARI, E. Is there a relationship between speech and nonspeech auditory processing in children with dyslexia? J. Speech Lang. Hear. Res., Rockville (MD), v. 44, n. 4, p. 720-736, aug. 2001.

SHIN, J. B. Temporal processing: the basics. Hear. J., v. 56, n. 7, 2003.

SAMELLI, A. G. O teste GIN (Gap in noise): limiares de detecção de gap em adultos com audição normal. 2005. 197 f. Tese (Doutorado em Ciências) - Faculdade de Medicina, Universidade de São Paulo, São Paulo.

SCHOCHAT, E.; MUSIEK, F. E. Maturation of outcomes of behavioral and electrophysiologic tests of central auditory function. J. Commun. Dis., New York, v. 39, n. 1, p. 78-92, jan.-feb. 2006.

SCHOCHAT, E.; RABELO, C. M.; SANFINS, M. D. Processamento auditivo central: testes tonais de padrão de frequência e de duração em indivíduos normais de 7 a 16 anos. Pró-Fono R. Atual. Cient., Carapicuiba (SP), v. 12, n. 2, p. 1-7, maio-jun. 2000.

TALLAL, P.; PIERCY, M. Developmental aphasia: impaired rate of non-verbal processing as a function of sensory modality. Neuropsychol., Oxford, v. 11, n. 4, p. 389-398, oct. 1973.

TALLAL, P. Auditory temporal perception, phonics and reading disabilities in children. Brain Lang., Orlando (FL), v. 9, n. 2, p. 182-198, mar. 1980.

THOMPSON, N. C.; CRANFORD, J. L. Hoyer Elmer Brief-tone frequency discrimination by children. J. Speech Lang. Hear. Res., Rockville (MD), v. 42, n. 5, p. 10611068, oct. 1999 .

WITTMANN, M; FINK, M. Time and language - critical remarks on diagnosis and training methods of temporalorder judgment. Acta Neurobiol. Exp., Warszawa, v. 64, n. 3, p. 341-348, 2004. 